\title{
BORDER SEXUALITY: IDENTITY EXPERIENCES AND INCLUSION PATHS OF WOMEN WITH NON- HETERONORMATIVE SEXUAL ORIENTATION BORN FROM MIXED COUPLES
}

\author{
Sexualidade fronteiriça: experiências identitárias e caminhos de \\ inclusão de mulheres com orientação sexual não heteronormativa \\ nascidas de casais multiculturais
}

Giuseppe Masullo* Carmela Ferrara**

\begin{abstract}
The article examines the processes of identification of women born from mixed couples (one Italian and one foreign parent), to explain the complexity in the self-determination processes of women with nonhetero-normative sexuality living in multicultural families. Based on the intersectionality paradigm, we will analyse how biosocial categories such as sex, gender, sexual orientation, class, name, skin colour, family background may influence the self-definition identity processes and generate multiple discrimination. Inspired by Gloria Anzaldúa's thoughts, we will highlight how girls shun widespread heteronormative models not only of mainstream society, but of the LGBT community itself. We also applied a methodology used in non-formal education, which allowed us to explore how the women interviewed put different aspects of themselves to the test, negotiating them in the different scenarios of everyday life, in an attempt to counteract situations for which they can feel stigmatized and oppressed.
\end{abstract}

Keywords: intersectionality; children of mixed couples; sexual identity; ethnic identity; stigma.

Resumo. O artigo examina os processos de identificação de mulheres nascidas de casais multiculturais (um parceiro italiano e o outro estrangeiro), para explicar a complexidade dos processos de autodeterminação de mulheres com sexualidade não heteronormativa que vivem em famílias multiculturais. Com base no paradigma da interseccionalidade, analisaremos como categorias biossociais como sexo, gênero, orientação sexual, classe, nome, cor da pele, antecedentes familiares podem influenciar os processos

\footnotetext{
Associate Professor of Sociology, University of Salerno. Fisciano - SA, Italy. E-mail: gmasullo@ unisa.it. Orcid: 0000-0003-0818-6981.

** Associate researcher GenPol - Gender \& Policy Insights. Cambridge, England. Orcid: 0000-00025687-9283.
} 
de autodefinição de identidade e gerar discriminação múltipla. Inspirados pelos pensamentos de Gloria Anzaldúa, destacaremos como as garotas evitam modelos heteronormativos comuns, não apenas da sociedade em geral, mas da própria comunidade LGBT. Também aplicamos uma metodologia utilizada na educação não formal, que nos permitiu explorar como as mulheres entrevistadas colocavam à prova diferentes aspectos de si mesmas, negociando-os nos diferentes cenários da vida cotidiana, na tentativa de neutralizar situações pelas quais elas podem se sentir estigmatizadas e oprimidas.

Palavras-chave: interseccionalidade; filhos de casais multiculturais; identidade sexual; identidade étnica; estigma.

Each of us should be encouraged to accept his own diversity, to see his identity as the sum of all his various affiliations, instead of as just one of them raised to the status of the most important, made into an instrument of exclusion and sometimes into a weapon of war. (Maalouf, 2005)

\section{Female migrations and "non-heteronormative" sexual orientation: the legacy of Gloria Anzaldúa's thought}

In her book, Borderlands/La Frontera: The New Mestiza, Gloria Anzaldúa (1987), Chicano feminism activist, writer, and lesbian (or rather queer as she liked to call herself), describes the experience of those who live on the "border". By this term, she means that psychological, social, and relational condition typical of migrants. When migrating to another country these people are affected by feelings of loneliness and nostalgia for their native land, not finding in the landing place any stable references for a far-reaching and inclusive identity anchorage ${ }^{1}$.

Gloria Anzaldúa recounts the experience of those who live the paradox of "being a foreigner in their homeland, an alien in their own land". For example, it is the condition experienced by many children of first-generation migrants. In many ways, second-generation immigrants in Italy experience daily the feeling of being "doubly strangers", neither fully belonging to their ancestral society of origin, that of their parents, which they often do not even know directly, nor to the immigration society. In the latter, they feel like half-citizens, due to stigma and discriminations suffered because of the colour of their skin, their ethnic origins, and cultural affiliations.

The reference to Anzaldúa, therefore, is crucial in so far as her concept of frontera allows us to introduce our research, still in progress, in

1 The paper was devised and written jointly by the authors. However, for the sake of authorship, sections 1, 2 and the conclusions are attributed to Giuseppe Masullo, while sections 3, 4 and 5 are attributed to Carmela Ferrara. 
which we examine the living conditions of mixed couples' daughters (i.e. one of the parents is foreign). In Italy, these young women find themselves in the remarkable situation of living at the intersection of several factors of discrimination: gender, ethnicity, and sexual orientation. The research aims at understanding how these women manage the ambivalence entailed in this particular living condition. They have to handle it on the psychological, identity, and also social level, since everything that makes them different from others may represent, depending on the context, a factor of both inclusion and exclusion.

Discussing Gloria Anzaldúa's work cannot leave aside the analysis of her biographical path which, as we will see, is closely related to the issues that, first as a writer, then as a queer and feminist, she will touch on in her main works. Beyond its literary value, Anzaldúa in her writings opens up to several disciplinary fields, ranging from anthropology, historiography, and of course sociology. Her works can be considered precursors of the issues addressed by the intersectional approach, both from a theoretical and methodological point of view.

Gloria Anzaldúa was born in Texas in 1942 and died in 2004. She was interested in redefining the Mexican-American cultural and gender identity, also because of her genealogical roots, being born from parents of Mexican origin and therefore descended from both the first Spanish colonizers and indigenous ancestors. She finished her studies in 1968, obtaining a degree in English and education sciences while she was actively involved in the Chicano feminist movement and the rights of gay and lesbian people. She began her $\mathrm{PhD}$ in 1974, which she abandoned in 1977 to focus on writing, having become interested in feminism and black feminist literature.

Anzaldúa committed her whole life to create a network of relationships between Chicano (or mixed-ethnicity) female authors and intellectuals, intending to analyse the condition of women between white and black culture. Furthermore, she wanted to offer a vision from within the transethnic communities of women struggling for their rights (Carbonara, 2013). Between the 1970s and the 1990s, Anzaldúa worked in and out of American universities, where the first ethnic studies were still struggling to be recognised. As Carbonara (2013, p. 2) writes: "on the one hand, it was necessary to impose oneself on to the white literary canon that was slowly progressing towards the inclusion of non-Euro-American writers' works, and, on the other hand, it was necessary to impose oneself outside and within the communities to which one belonged, in some cases discriminating against women".

Anzaldúa's collaboration with these scholars led to her first collected works, such as This Bridge Called My Back: Writings by Radical Women of 
Color together with Cherríe Moraga (1983), and Making Face, Making Soul / Haciendo Caras: Creative and Critical Perspectives by Women of Color (1990). In them, Anzaldúa pursues the formation of a trans-ethnic sisterhood that restores dignity and recognition to all those women who, because of their multiple belonging - because they live at the intersection of several vectors of oppression, (related to race, gender, and sexual orientation) suffer discrimination and violence. Her analysis will be centred precisely in addressing the issues of "crossbreeding" and cultural hybridization from a non-mainstream point of view.

Recounting the experience of the Chicanos of which she is part - a population that symbolically lies on the border between Mexico and the United States - Anzaldúa can help us understand the condition experienced by many LGBTQI migrants in our country, some of whom emigrate not only because forced by need but also because of the impossibility of living their sexual orientation in their homeland.

In Borderlands / La Frontera: The New Mestiza, Anzaldúa describes the condition of those who feel oppressed because they experience being at the "border" both from a territorial point of view and on the sexual, spiritual, and psychological level, about the various sides of their self (Agressi, 2003). This was the condition experienced by the writer: as a Chicano woman and a lesbian, she met with difficulties in relating to both the dominant white society and her native community. Anzaldúa's analyses do not stop at the American society, also addressing the adversities encountered by women in the Chicano community, imbued in the 1960s with sexism and homophobia. For Carbonara (2013), the movement for the affirmation of black people's rights had influenced the Chicano community:

Chicanism pushed for the identification of the race, with the legendary Aztec territory of Aztlán with the virility of the ancient warriors (...) They were essentially 'masculine' movements, that badly tolerated what was considered the influence of the white bourgeois feminist ideology on the women of the coloured communities. (Carbonara, 2013 p. 16-17)

Describing the experience of the Chicanos, Anzaldúa adds the question of gender and sexuality to the race and social class of belonging. She considers these aspects as core factors of further discrimination in both the community of origin and that of immigration. Reinterpreting tradition, inspired by the mythical figure of the goddess Coatilcue, Anzaldúa fully embraced the novelties introduced by the affirmation of "queer", a concept born within deconstructivist theories which refused all forms of pre-categorization about sexual identity, thus claiming the possibility of the coexistence of a border 
identity and opposing all forms of gender (male/female) and sexual orientation (hetero/homosexuality) duality².

The encounter with the term "queer" allowed Anzaldúa to reach her most important concept, that of mestiza identity, rejecting any attempt at being labelled according to race, gender, or sexuality. As Pasquino (2006) writes, queer must be understood as an open category

that can never be said to be complete and that establishes perennially provisional identities. The term is not synonymous with homosexuality as it addresses all sexual subjects caught between binary categories, hybrid subjectivities and bodily margins: transsexuals, transgender, transvestites and transvestites, intersex, androgynousness, etc. More generally, the term 'queer' indicates otherness and outlines the contours of a precarious, fluid, mobile subjectivity, which summarizes the struggles of those who fight against every binary opposition. (Pasquino 2006, p. 2)

In an interview from the 1990s, Anzaldúa defines this feeling with two chosen terms. The first, "rapture" (arrebato), is understood as a form of internal opposition to all those identity attributions with which "others" want to label her; the second, "edge" (orilla), is the place where people who experience this condition live, both consciously and unconsciously (Zaccaria, 2000). In several passages of the interview, using evocative figures linked to her culture of origin, she describes this state and the political meaning that the concept of mestiza can assume:

One of the visual images through which I tried to convey all this was a stylized figure with all these different legs and all these different worlds: Jewish, heterosexual, queer, white, academic, campesina. You know, all the different worlds in which people navigate daily, and so this stylized figure with all these different legs represents the different communities, the different cultures. (Zaccaria 2000, p. 51)

For the Chicano writer, those who live in the borderlands have a mestiza identity because they experience their own hybrid identity on a daily basis: living between two worlds, multilingualism, the attraction for different value systems to which they never fully adhere. It is a context in which one accepts one's ambiguity, in which there is no contrast (such as that between homosexuality and heterosexuality), but rather a space to be crossed opening up to the idea of the existence of multiplicities.

In recent years, Anzaldúa's concepts have proved useful in many academic disciplines to describe the identity of those who live in places of

\footnotetext{
2 Queer Theory was born with the conference organized by Teresa De Lauretis in 1990 at the University of Santa Cruz entitled Queer Theory. Since then, "The works brought together (in part retrospectively) under the 'queer' insignia has made it possible to create space for fruitful reflection, concerning historical questions about sexual typologies, the possibility of making the sexual sphere autonomous from gender issues (...) and the greater visibility given to different sexual subcultures and transgender identities. (...)" (Chauvin, Lerch, 2016, p. 22, personal translation).
} 
encounter - clashes between cultures, showing the disparities existing between the centres of power and the peripheries of the globalized world, as well as giving rise to exchanges between them. The border, the frontier, have thus become powerful images, used as symbolic figures to describe the physical and emotional condition of those who live "in-between". As mentioned above, this concept is particularly useful for those researches focused on subjects who experience multiple discriminations linked to the crossing of several vectors of oppression, as in the case of homosexual migrants, discriminated both for their ethnic and racial belonging and for their gender and sexual orientation (Mangone, Masullo, Galego 2018). The concept of mestiza was born to highlight the condition of the migrant and queer woman who, because of her overlapping diversities, is divided between the need for belonging and the desire for freedom, between attachment to her cultural roots and the need to embrace the opportunities offered by the country of immigration.

Katie Acosta (2008), for example, uses the concept of mestiza to describe, in a recent study, the experience lived by lesbian emigrants of Latin origin in the United States, and how they experience every day their mestiza condition by shifting along the borders of their various affiliations. The boundaries are constantly broken and reworked by these women, in some cases reinvented, to freely live their sexual orientation. The discrimination they experience within American society and their ethnic communities leads them to build imaginary communities within which they feel themselves, offering support and help to those who live the same condition, migrant women, and homosexuals. For Magnarin (2013), however, this experience is not without suffering, considering the fear experienced by homosexual immigrant women in countries of immigration and the attempt to adhere to the traits of the dominant culture, putting aside some traits of themselves that must remain hidden.

If suffering is the common trait among those living at the border, who experience a mestiza identity, it is also true that the border can represent an opportunity, a way through which "uprooted people can question the dominant models and deconstruct the categories. It is fertile ground for imagining new visions of the world capable of leaving the subject free to express and define herself, reinterpreting her identity and living her eccentric and out-of-theordinary being more freely" (Magnarin, 2013, p, 246). Indeed, these are the traits that unite all the life stories examined, which we will present in the following sections.

\section{Research design and methodological aspects}

In the following pages, we will examine the life stories of three non-heterosexual girls born from mixed couples (i.e. one of the parents is of foreign origin) as significant examples of the experiences of foreign 
women who, presenting a non-regulatory sexual orientation, find themselves facing more factors of oppression and discrimination. We will apply Gloria Anzaldúa's concepts and more generally the theoretical orientations belonging to the intersectional and postcolonial theories ${ }^{3}$. Although we are aware of the differences between being a child of a mixed couple and the living conditions of children of other types of foreign families, we believe that the considerations valid for the latter can be extended in part to the former, as we will be able to highlight further on by reading the results through an intersectional lens.

While Italian sociology has focused, over the last few years, on subjects that migrate to other countries because of their sexual identity, it has done so in an exclusively male direction. To date, the condition of the migrant, lesbian, transgender, and queer woman remains an aspect still little explored by sociological studies. In our opinion, these difficulties are attributable to both theoretical and methodological reasons. Among the former is the fact that the current research paradigms on migration studies, at least in Italy, show a markedly heteronormative orientation. With this term, we mean "the set of hierarchizations and stratifications that define the symbolic-discursive universes according to the dichotomous matrix of gender and social roles associated with them" (Rinaldi, 2013, p. 16). This implies that one can be exclusively either a "male" heterosexual or "female" heterosexual, all other possibilities are not taken seriously. An emblematic example is that of migrant women, often framed by a logic reducing them to their gender (e.g. in work-focused research), reproductive health or, in case of deviance, the problem of prostitution. Sexual identity, for example, is never mentioned among the reasons why a woman chooses to migrate (Masullo, 2015). A second reason is methodological, connected to the general invisibility experienced by lesbianism and bisexuality (particularly in Italy) due to a double process of stigmatization (which for migrants becomes triple). The joint action of sexism, racism and homophobia further complicates the possibility of publicly disclosing one's sexual identity. In our opinion, this difficulty in finding subjects willing to tell their story greatly hinders research on this sector. Given the difficulties in finding interviewees, we employed a snowball sampling system, as the literature shows that it is the most suitable method in case the population is composed of subjects who tend to hide their identity or are difficult to find (Silverman, 2008).

The research took place between August 2019 and the end of January 2020 and the first problem we faced was finding the respondents. After several attempts and refusals - particularly from first-generation immigrant women

\footnotetext{
3 For Rebucini (2011), considering these experiences as the product of colonization leads to the search for solidarity and alliance built around the category of "Third World Countries of the United States", thus uniting "these movements for social justice not only among themselves but also with global movements for decolonization" (Rebucini, 2011, p. 7).
} 
(contacted through the LGBT associations' Migrant Information desks ${ }^{4}$ ) we met by chance a young woman of foreign origin, daughter of a mixed couple. Her openness and availability led us to reflect on what conditions could help access the cases for our research. Undoubtedly, the fact that researcher and interviewees shared certain identity and cultural traits (e.g. nationality, language, non-heteronormative sexual orientation) determined the confidence necessary for some of them to be willing to be interviewed. From a random feature, focusing on the second generation has then become a choice and a central aspect. Indeed, second-generation young women, for their specific border position (identity, cultural, social) better represent the dilemmas experienced by migrants with a non-heteronormative sexual orientation. They experience more forcefully the (often painful) tension generated by living at the crossroads of a multi-belonging that causes greater opportunities for disadvantage and discrimination.

We followed the biographical methodological approach, where life stories are considered important for their ability to shed light on the microsociological and identity processes here examined, rather than for the generalizability of the knowledge that they provide on a given phenomenon. Of the various definitions of life stories offered by the literature on the subject, we chose Atkinson's (1998, p. 28): a life story is that story "as complete and honest as possible, which a person chooses to tell about the life she has lived. It is constructed from what the person remembers about her life and the aspects of it that the person wants others to know, as a result of an interview led by another person". This definition is preferable to the others since it highlights a fundamental aspect, namely "the biographical pact" the fact that the story is as complete and honest as possible, but also inevitably partial and discretionary.

Three women agreed to be interviewed, but the research is still in progress, so the following considerations should be considered as partial, useful to identify an "ideal type" of the condition experienced by daughters of mixed couples with non-heteronormative sexual orientation, compared to possible configurations that interviews and further insights will allow us to achieve in the future. The women were invited to tell their lives following a semi-structured interview from which the interviewers tried to unearth the interviewees' world, their universe of meaning, their intersectional discursive practices.

\footnotetext{
4 As recounted by some operators of LGBT migrant information desks (designed to help people to apply for refugee status), women with a non-regulatory sexual orientation rarely make use of them. It is not uncommon to find particularly dramatic experiences, considering that in some contexts LBT women are often victims of violence and mass rape, hence also the difficulty to speak freely about it.
} 
As Bichi (2004) points out, there are different types of analysis of life stories, which vary according to the articulation of the relationship between theoretical and empirical dimensions. Given the extraordinariness of the stories collected, the scarce previous knowledge on the subject, and above all, our desire not to include the categories used by the interviewees, we chose an analytical approach in which "the word of the interviewees is considered transparent, able to provide by itself the meanings useful for the understanding of social phenomena" (Bichi 2004, p. 148). Therefore, the stories are preceded by descriptions aimed at providing context and directing the reader's gaze towards the preeminent features, rather than at justifying the researchers' hypothesis ${ }^{5}$.

\section{Neither inside nor outside: the experience of being at the "border" of cultural belonging.}

Leyrin, Jadia and Yasmine ${ }^{6}$ are three women born to an Italian and a foreign parent. We collected their stories intending to delineate the complexity of the self-determination processes of women with non-hetero-normative sexuality living in multicultural families. Starting from Anzaldúa's suggestions, enriched by references to the intersectionality paradigm (Marchetti, 2013) we analyse how biosocial categories such as sex, gender, sexual orientation, class, name, skin colour or family background can influence the processes of self-definition of their identity and generate multiple discrimination.

It is possible to trace common paths among the life stories of the interviewees, starting from the difficulty of recognizing themselves as belonging to one or the other nationality.

The fact of being the daughter of a mixed couple weighed heavily on me as a child, because, as it often happens, I was not Italian enough to be here, nor Tunisian enough to be there. (Jadia)

For the daughters of an immigrant father, the somatic characteristics which for children of an Italian mother and Tunisian father are less impactful, as they are both Mediterranean - are added to their non-Italian name and surname (in this case, Arabic).

When I was little, I used to tell my mother that I felt Tunisian in Italy and Italian in Tunisia. The thing that weighed on me the most was my name, the fact that people didn't understand it immediately, asked me to repeat it, they mispronounced it. (Yasmine)

\footnotetext{
5 On this issue, Daniel Bertaux (1999) writes that a life story deserves to be published in extenso only under exceptional conditions, as it is the product of many interviews, the result of a concentration of efforts on one person, particularly rich and accompanied by a valid argument on the typicality or representativeness of the case in question.

6 To protect the interviewees' privacy and personal data, the names used here are fictional.
} 
The migration story of the foreign parent changes according to their gender. In Leyrin's case, the daughter of a Dominican woman, we can see the double stigma suffered by her mother when she arrived in Italy.

A lot of things about her country were too small for my mother, she felt cramped there. She had always been an artist, she studied Italian and dreamed of coming to Europe, imagining Italy as an evolved country where art is appreciated and therefore where she could finally express herself. Her initial idea was to settle here and have her brothers come to Italy and free them from the heavy family situation. Unfortunately, this was not the case, because her marriage with my father turned out to be a big obstacle. She had not come here intending to get married. She met my father there because he was on holiday and they started corresponding. But she came here with the support of her neighbours' children living in Rome. Precisely I don't know what happened exactly, but once she arrived in Rome, she had no official invitation and without this document, she could not have left the airport. My father was informed of this, prepared the necessary documents and returned the next day. There, my mother suffered the first racist discrimination. Just as she was stopped at the airport, other foreign people, mainly from Eastern Europe, were also stopped. That night my mother was raped and was filled with despair. She didn't expect her first night in Italy to be like that. Early in the morning, the cleaners saw her and one of them exclaimed "these black people, they've barely arrived and they're already doing these things"; it was a clear allusion to prostitution. (Leyrin)

On their fathers' migration, Jadia and Yasmine say:

My father was in his twenties when he arrived in Italy. I think he came for the first time when he was 19 or maybe even less, he was in Sicily for a while, then I think he got demoralized, came back home and after a year he left again. I don't know exactly what year he arrived in Italy. He is an economic migrant, but I think it was also a matter of lifestyle. Speaking with him, I happened to understand that the Tunisian mentality of the time felt a bit too small for him. (Yasmine)

In all three cases, the parents are divorced. According to ISTAT (Multipurpose Survey of Families, ISTAT 2014) over 70\% of mixed marriages end in separation or divorce. Here too, the gender of the immigrant parent is decisive. In all three stories after the separation of the spouses, the daughters stayed with the mother.

\section{Defining sexual identity: between stereotypes and negotiation processes}

With regard to becoming aware of their affectivity and non-heteronormative sexuality, Leyrin, Jadia and Yasmine all found it difficult to define their sentimental and sexual orientation, feeling a certain difficulty in defining oneself through binary categories (heterosexuality/homosexuality). Just as they struggled to define their cultural identity, they struggled to define their affectivity and sexuality in a binary way. 
During my adolescence, I refused any definition and my knowledge of various sexual orientations was scarce. For me, only the definitions of "straight" and "gay" existed and I didn't recognize myself in either and I just lived by following my instinct, without defining myself. Growing up I started asking myself questions about my identity, wondering "what the heck am I?" [laughter] In the beginning the notion of bisexuality did not convince me, I was ignorant about the subject, I imagined bisexuality as sexual attraction to males and females in the same way and in a very binary way. Today I know that bisexuality is the sentimental and sexual attraction to two or more genders, but since I discovered the term pansexual I have found a definition in which I feel more comfortable. (Leyrin)

I have identified myself as bisexual since I was about 14 years old, then only recently, approaching the LGBT world I realized that I identify myself more as pansexual, more as panromantic and not monogamous. (Jadia)

Understanding how their coming out has been greeted and experienced in the family allows to acquire knowledge about the parents' perceptions of homosexuality, especially for those of foreign origin. The interviews show that the parents of all three girls present a fairly liberal view of sexuality, contrary to what one would expect from parents of Maghreb origin, for example, given that in Morocco homosexuality is punished by imprisonment. This factor (and others emerging from the following excerpts) not only leads to a non-stereotypical reading of the parents' cultures of origin but also highlights the difficulties of these young women to correspond to the stereotypes that their parents themselves have elaborated about homosexuality.

In Leyrin's experience, for example, coming out with the family, for example, was facilitated by the fact that she had other relatives who were already declared homosexual.

My family's reaction was not at all a reaction of surprise, the answer was "we already knew". My mother, who is the first daughter, has two younger brothers who are both gay. So, let's say she was prepared. Now one of my uncles still lives in the Caribbean, while the other one works in Canada. I was lucky because not only did I know I had two homosexual uncles, but I also met their various boyfriends. I had the opportunity to talk to them about their experience and they told me that in the Dominican Republic society is very patriarchal and my grandparents came up with phrases like "gays should be burned alive". So, the younger brother, seeing these reactions, took a long time to come out. (Leyrin)

For Jadia, instead, it was her mother who outed her with her father, with whom she had difficulty in talking about the subject.

I came out with my mom while I was keeping her company at work, she was cleaning in a school, and while she was washing the floor, I told her: "mom, I think I'm bisexual" and she said: "with women, I think it's more of an emotional issue, honey". In my mom's eyes, when I was 14, I was an asexual little angel, so she didn't consider the sexual sphere. (Jadia) 
With my father, I never came out, but less than a year ago, around the time of the Pride, my mother outed $\mathrm{me}^{7}$. In fact, she was even about to tell him about my coming out as polyamorous because I had talked to her and my sister about my relational anarchy, trying to simplify everything by calling me polyamorous. Now I still have to identify myself well on this, I still don't know how I feel, I'm studying myself [laughter]. She refrained from saying this thing and just said: "what if our daughter fell in love with a woman too?" and my father's answer was: "yes, I noticed it, it shows". Now, I don't know what "shows", I haven't been investigating, because it's already quite difficult to talk about these matters with my father, with all the cultural and linguistic obstacles. We speak in Italian, but he doesn't have full mastery of the language, let alone in this field which is specific and constantly evolving, so I said to myself: "let's leave it at that with the idea that it shows, it doesn't matter", I have to start to feel good about myself. Getting into LGBT vocabulary with him was something I wanted to spare myself [laughter]. He didn't have a negative reaction when I confirmed that I liked women as well, in fact, he worries much more when he knows that I am with a man. I was very surprised by his calm reaction. I didn't really know what to expect, I was prejudiced given his cultural background. Technically, he's a Muslim, but then he's very flexible, he loves ham, he's integrated, so to speak [laughter]. (Jadia)

Yasmine says that she never had a real coming-out. While she spontaneously talked with her mother about her sexual orientation, she had many difficulties with her father because of his cultural background. Now that she has a relationship with a Moroccan woman, she believes that her partner's origins have facilitated the process of acceptance of her sexuality.

When I think about coming out, I can't think of a specific moment, I happened to be asked, but I don't know whether to consider it as coming out. I didn't come out with my mother, in the sense that the moment I started asking myself questions I talked to her and therefore she found out with me. I never felt I had to tell my father [laughter] he understood it by himself and, after a while, he asked me explicitly. We were talking about a friend of mine and out of nowhere he said: "but is she a lesbian?" I said "no" "and you?" I answered "mmm... more or less" [laughter] and at that time I said I was bisexual because it seemed the easiest thing to explain, but actually, I said "technically - I was 22 - 23 years old - I am bisexual". He had already understood for a while, like a couple of years and also thanks to his partner, who is now his wife, he made a psychological journey on this thing too. When I told him this, he said to me: "what does it mean?" He had already sent me signals several times saying: "if you want you can talk to me", but I always pretended acted like nothing happened [laughter]. His reaction was like: "I accept it, but I'll never understand it". After a while, I got involved with a girl of Moroccan origin and I think this helped his acceptance process a little bit, I don't know, I had this feeling, because somehow, being of Arab origin herself, she created a greater closeness. I don't know if my father would call himself a Muslim; if he did, it would be because of a cultural issue, because he is not a practitioner. (Yasmine)

7 We remind readers of the difference between the terms coming out (spontaneous declaration of one's sexual orientation) and outing (disclosure, without the person's consent, of their sexual orientation). For further information please see Valerio et al. (2013). 


\section{The identity processes of those living at the intersection of several factors of oppression}

Inspired by Gloria Anzaldúa's thought, to stitch together the identity traits emerged from the life stories of the three women interviewed, we created the identity molecules. This is a methodology used in non-formal education for the exploration of identities and the intersection between their various dimensions and then identify the element recognized as most distinctive ${ }^{8}$.

We asked the interviewees to insert in each atom of the molecule an element characterizing their own identity. In the following section, we will present the results.

Figures 1., 2. and 3. - relative to the identity molecules of Leyrin, Jadia and Yasmine, respectively - show that each woman, to synthesize their identity through four categories, refers to gender identity, sexual orientation, ethniccultural belonging to non-Italian roots.

Fig 1 - Leyrin's Identity Molecule

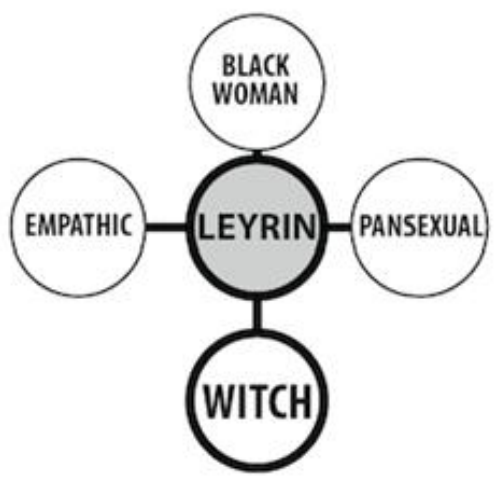

Leyrin's identity molecule was built by identifying first her skin colour as an element strongly characterising her identity. In the first atom, we thus find "Black woman". Sexual orientation is the second element that we find in Leyrin's molecule: "pansexual", from the Greek -pan, all, a definition that indicates as irrelevant characteristics the sex and gender of the chosen partners.

"Witch", in Leyrin's identity, encapsulates both her spirituality and her interest in medicinal herbs, as well as the recovery of ancestral practices

${ }_{8}$ More information on the instrument can be found at: <https://www.salto-youth.net/tools/ toolbox/tool/identity-molecule.389/>. 
linked to the cultural identity she feels she carries in her genes as if it were an inheritance.

(...) Because it represents my spirituality but also my practical side that I would like one day to be able to define my professional identity, this is perhaps currently my greatest need, to affirm my identity as an adult and I hope to make my passion for medicinal herbs my work.

This discovery evoked memories that I had removed, related to my childhood, and linked to my mother's culture. Before I used to see her a bit like a witch [laughter] now she has approached Christianity and says she is in love with Jesus Christ, but I assure you she is not a bigot like most Italians who live a convenient Catholicism - I am thinking of my paternal grandparents, for example. She really embraced true Christian values. The Catholicism that she experienced as a child, however, is very different from what she is confronted with here; there it is very much associated with santería and voodoo. It's a bit like the fusion born of Catholicism at the time of the conquistadores with the traditional culture of the natives. For my part, I am very spiritual but not very religious. I believe a lot in lunar and planetary influences, just as I believe a lot in respect for nature and animals because we are all born from the Bing Bang, all beings are interconnected and all forms of life must be respected. For me, in nature there is all the God I need, because He provides us with everything we need to live, sun, water, flowers, plants of which many are medicinal herbs and my partner and I often use them to create infusions. (Leyrin)

Fig 2 - Jadia's Identity Molecule

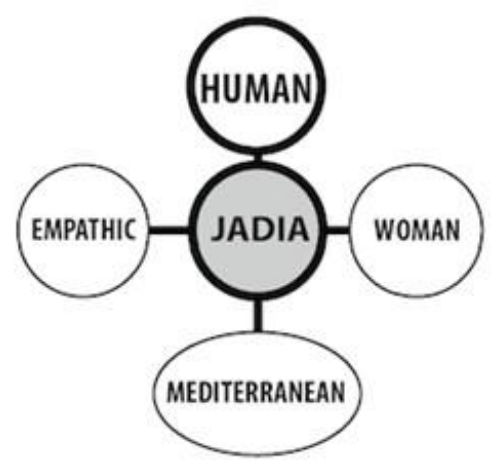

Jadia chooses to define herself as most importantly "Human", as if to specify that, beyond all the categories that can describe a person, what characterizes everyone indiscriminately is the belonging to the human race. Gender, however, is the element that Jadia identifies as fundamental in the definition of her identity. After being human, we are women, men, non-binary people. "Woman", then, as we can see from figure 2, is the word associated with the second atom. The difficulty to pinpoint her cultural belonging leads Jadia to define herself as "Mediterranean"; even if it is a wide and little defined geographical area, it gives her the possibility to place her roots in the world. 
Finally, both she and Leyrin identify in empathy an attitude that characterizes their identities.

Fig 3 - Yasmine's Identity Molecule

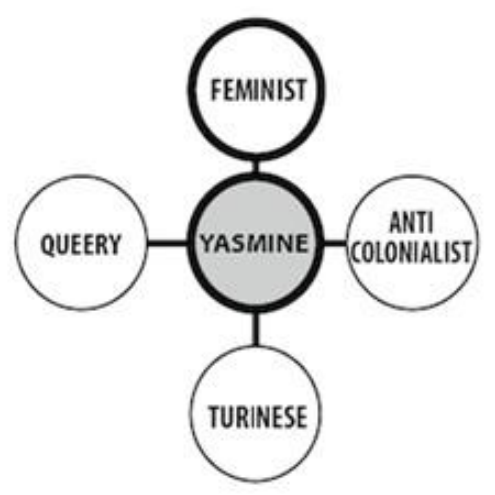

Yasmine, in building her own identity, chooses to define herself first and foremost as a feminist. She explains that she has not chosen "woman" but "feminist", because for her being a feminist as a woman means giving space to all women. The second atom of the molecule is "Anticolonialist". Yasmine says she feels a strong sense of Western guilt, the sense of guilt of the oppressor, so being anti-colonialist is almost a duty for her, who carries in her identity the characters of two peoples. But more than an Italian, she feels a Turinese. The sense of belonging to the city more than to the nation - she says - is because Turin is a context that makes you connect to its spaces and cultural ferments. Finally, she defines herself as "Queer", because with that word she describes both her emotional sphere outside the hetero-normative canons and the way she is perceived as not conforming to the norm.

We transsexuals are migrants in every sense, migrants of gender and in general, towards a body more our own, towards a more familiar country, towards a less hostile land - as Porpora Marcasciano writes in Favolose Narranti. (Yasmine)

\section{Conclusions}

The priority given to the interviewees' voices and the few cases examined do not dispense us from trying to provide, in this last section, a reading of the processes described. We will try to highlight common aspects and differences between the stories, attempting to enrich our reflections and future research paths. The young women interviewed share social positions that make them borderline subjects in Gloria Anzaldúa's terms: not only concerning sexual identity but also to other sides of the self, such as gender, cultural affiliations, skin 
colour, even their name. This makes their stories unique and, in this phase of the research, difficult to ascribe to interpretative categories for the creation, for example, of ideal types. If we define identity as a concept that can be examined through multiple levels of analysis (personal, cultural, social), it emerges that the young women interviewed have difficulty, for example, in recognizing their cultural affiliation, an aspect that partially equates their experiences to those of other second-generation migrants. On this issue, it is useful to remember Sayad's words (2002) in his famous essay La double absence. Des illusions de l'émigré aux souffrances de l'immigré, in which he highlights how: "The presence of the immigrant is always marked by incompleteness, it is guilty in itself. It is a presence out of place (déplacée) in every sense of the term" (Sayad, 2002, p. 373). This feeling should not pertain to children of mixed couples; their legal status is being "Italian" citizens in all respects. Yet feeling "out of place", perceiving themselves as bearers of a "hybrid" identity, emerges strongly from the interviews. It is not enough to have an Italian parent, to be born in Italy or to enjoy full citizenship status to feel "Italian". The intersectional theory allows us to grasp how this perception is linked to other factors (such as skin colour) and that identity requires recognition by the other before anything else. Our interviewees feel in some ways like others - and therefore recognized as such - but for other traits they feel different and therefore experience a sense of estrangement and are victims of discrimination. This was also evident about sexual identity, for example, where girls are shunned by heteronormative models that are widespread not only in mainstream society but in the LGBT community itself. It is not uncommon to experience here forms of distrust towards those women who do not recognize themselves as such and define themselves in non-binary terms, and therefore towards those who define themselves as "queer" and "pansexual":

During high school, my skin colour stopped being a problem and I was targeted for my gender expression not conforming to the female gender expression and for not having a straight sexual orientation. Many thought I wanted to be a rebel, others thought I was weird, but the most painful thing was being considered "confused" by some LGBT people or even zoophile by some ignorant people. When I was dating girl,s I was recognized as part of them, but when I was with boys it was as if I became heterosexual. I think a lot of bisexual and pansexual people suffer from this, from the lack of recognition of their whole identity. (Leyrin)

But the most important aspect that intersectional theory emphasizes is that the discrimination one suffers should not be considered individually but rather as the: "the result of the combination of two or more identity categories, which generates a peculiar experience qualitatively distinct from the sum of its components" (Scamardo 2003, p. 136). We can, therefore, add racial discriminations to those experienced by these young women because of their 
sexual identity, due to the survival of stereotypes that often emphasize black women's "exotic" customs and licentious sexual behaviour.

Anzaldúa's thought, which can be ascribed to this branch of studies, allows us to observe how people coordinate the different "ways in which we present ourselves to the world" and how, despite these differences, the young women interviewed manage to have a unified vision of themselves. We can see, therefore, the active role that the women interviewed have in testing the different aspects of themselves, in negotiating them in the different scenarios of everyday life, in an attempt to counteract situations for which they may feel stigmatized and oppressed. Different strategies emerge here, each of which can lead to multiple readings. For example, Leyrin's choice to define herself as a "witch", Jadia's choice to emphasize her being simply "Human" and Yasmine's choice to declare herself a "feminist" - how can they be interpreted? Can they hint at the desire to feel accepted in a society where, because of the simultaneous action of sexism and racism, women are read through stereotypes that belittle their identities? Or should they be interpreted as an attempt at resistance, at rejecting any attempt to "frame" their identities within pre-categorizing schemes? What are the factors that push these young women to choose to valorise some traits over others?

How do these choices vary according to the contexts in which the interviewees move - e.g. what meaning do definitions such as queer or pansexual take on in the broader framework of identity strategies implemented by them within the LGBT community?

These are some of the questions that this ongoing research will have to answer in the future.

\section{References}

ACOSTA, Katie L. Lesbianas in the Borderlands. Shifting Identities and Imagined Communities. Gender \& Society, v. 22, n. 5, p. 639-659, 2008.

AGRESSI, Ada. Mestizaje Americano: Gloria Anzaldúa. Annali di Ca' Foscari, v. XLVI, p. 5-27, 2007.

ANZALDÚA, Gloria; MORAGA, Cherríe (eds.). This Bridge Called my Back. Writting by radical woman of color. New York: Woman of color Press, 1983.

ANZALDÚA, Gloria. Terre di confine/La Frontera. Bari: Palomar, 1987.

ANZALDÚA, Gloria (ed.). Making Face, Making Soul / Haciendo Caras: Creative and Critical Perspectives by Women of Color. San Francisco: Aunt Lute, 1990.

ATKINSON, Robert. The life story Interview. London: Sage, 1998.

BERTAUX, Daniel. Racconti di vita. La prospettiva etnosociologica. Milano: FrancoAngeli, 1999.

$\mathrm{BICHI}$, Rita. L'intervista biografica. Una proposta metodologica. Milano: Vita e Pensiero, 2004. 
CARBONARA, Lorena. Senza riserve. Geografie del contatto. Bari: Progedit, 2013.

CHAUVIN, Sébastien; LERCH, Arnaud. Sociologia dell'omosessualità. Torino: edizioni Kaplan, 2015.

MAALOUF, Amin. L'identità. Un grido contro tutte le guerre. Milano: Bompiani, 2005.

MAGNARIN, Laura. Percorsi di vita dei migranti LGBTQ tra sradicamento e resistenza. DEP-Rivista telematica di studi sulla memoria femminile, n. 21, p. 236246, 2013.

MANGONE, Emiliana; MASUlLO, Giuseppe; GALLEGO, Mar (eds.). Gender and Sexuality in the Migration Trajectories. Studies between the Northern and Southern Mediterranean Shores. Charlotte, United States: Information Age Publishing (IAP), 2018.

MARCHETTI, Sabrina. Intersezionalità. In: BOTTI, Caterina (ed.). Le etiche della diversità culturale. Firenze: Le Lettere, 2013, p. 133-148.

MASULLO, Giuseppe. Migrant Sexualities: "Non-normative" Sexual Orientation between Country of Origin and Destination". Italian Sociological Review, v. 5, n. 3, p. 383-398, 2015.

PASQUINO, Monica. II queer, la trasformazione dello spazio pubblico e il concetto filosofico di performatività. 2006. Available at: <https://docplayer.it/3369225Il-queer-la-trasformazione-dello-spazio-pubblico-e-il-concetto-filosofico-diperformativita.html>. Accessed: 11.01.2020.

REBUCINI, Gianfranco. Théories féministes et queers décoloniales: interventions Chicanas et Latinas états-uniennes. In: Les cahiers du CEDREF. Paris, Éditions iXe, p. 6-11, 2011.

RINALDI, Cirus. Sesso, sé e società. Per una sociologia della sessualità. Firenze: Mondadori Università, 2018.

SAYAD, Abdelmalek. Doppia Assenza. Dalle illusioni dell'emigrato alle sofferenze dell'immigrato. Milano: Raffaele Cortina editore, 2002.

SCARMARDO, Maurilia. Intersezionalità e riflessioni sull'omofobia. In: RINALDI, Cirus (ed.). La violenza normalizzata. Omofobie e Transfobie negli scenari contemporanei. Torino: Edizioni Kaplan, 2013.

SILVERMAN, David. Manuale di ricerca sociale e qualitativa. Roma: Carocci editore, 2008.

VALERIO, Paolo; AMODEO, Anna Lisa; SCANDURRA, Cristiano. Lesbiche, Gay, Bisessuali e Transgender. Una guida dei termini politicamente corretti. 2013. Available at: < file:///Users/Giuseppe/Downloads/LGBT_Una_guida_dei_termini_ politicamente_corretti\%20(1).pdf $>$.

ZACCARIA, Paola. Mettere insieme Coyolxauhqui. Intervista con Gloria Anzaldúa. Ácoma: Rivista Internazionale di Studi Nordamericani, v. 20, p. 50-56, 2000. 